This PDF is a selection from an out-of-print volume from the National Bureau of Economic Research

Volume Title: Tax Policy and the Economy, Volume 14

Volume Author/Editor: James M. Poterba, editor

Volume Publisher: MIT Press

Volume ISBN: 0-262-66164-0

Volume URL: http://www.nber.org/books/pote00-2

Publication Date: January 2000

Chapter Title: Stock Market Reaction to Capital Gains Tax Changes: Empirical Evidence from the 1997 and 1998 Tax Acts

Chapter Author: Douglas A. Shackelford

Chapter URL: http://www.nber.org/chapters/c10847

Chapter pages in book: (p. 67 - 92) 


\section{Stock Market Reaction to Capital Gains Tax Changes: Empirical Evidence from the 1997 and 1998 Tax Acts}

\section{Douglas A. Shackelford}

University of North Carolina and NBER

\section{EXECUTIVE SUMMARY}

This paper analyzes the impact of changes in capital gains taxes on equity values. Seven necessary conditions are outlined for stock prices to be affected by a change in the taxation of long-term capital gains. Specifically, the marginal investor must be an individual, investing for the requisite holding period, selling in a taxable disposition, and compliant. His short-term capital gains from all investments equal or exceed shortterm capital losses, and his long-term capital gains from all investments equal or exceed long-term capital losses. In addition, the capital gains tax change must alter the investor's expectation of the taxes that will be generated when he sells in the future, and inelasticities in the supply of capital must prevent immediate economic readjustment.

The paper then reviews four studies that estimate the stock market reaction to capital gains tax changes in the Taxpayer Relief Act of 1997 and the Internal Revenue Service Restructuring and Reform Act of 1998. The recency of these legislative changes and the conditions under which they were enacted provide useful settings for recalibrating the relation between stock prices and capital gains taxation. 
Although evaluating different firms and event periods, the studies generally find:

- Stock prices react to changes in the capital gains tax policy.

- Stock prices react quickly to information about tax legislation.

- The stock price reaction is largely complete by public announcement of the change.

- The magnitude of the stock price reaction is material.

These findings join a growing literature documenting that capital gains tax policy plays a role in establishing equity values.

\section{INTRODUCTION}

Capital gains tax policy has entered a new phase of legislative uncertainty. From 1987 to 1997 , individuals faced a maximum U.S. statutory capital gains tax rate of 28 percent on investments held for more than one year. Since then, Congress has reduced the long-term capital gains tax rate and adjusted the holding period twice.

The Taxpayer Relief Act of 1997 (TRA 97), which became law on August 5,1997 , lowered the maximum statutory long-term capital gains tax rate for individuals from 28 to 20 percent, effective May 7, 1997. After July 28, 1997, the lower rate was restricted to property held for more than 18 months. Investments held for more than 12 months, but not more than 18 months, faced the 28 percent tax rate. TRA 97 did not change the rate applied to investments held for one year or less. They continued to be taxed at the ordinary income tax rate, which caps at 39.6 percent.

The 18-month holding period was short-lived. On July 22, 1998, the Internal Revenue Service Restructuring and Reform Act of 1998 (IRSRRA 98) repealed the 18-month holding period, effective January 1, 1998. Thus, investors currently enjoy a maximum 20 percent long-term capital gains tax rate on all purchases held for more than a year.

This summer Congress attempted to reduce the long-term rate further. On August 5, 1999, Congress passed the Taxpayer Reform and Relief Act of 1999, which would have reduced the maximum individual capital gains tax rate to 18 percent, effective January 1, 1999. Although President Clinton vetoed the bill on September 23, 1999, speculation remains that a compromise bill may materialize.

With each of these legislative initiatives, there has been no consensus about the impact of the capital gains tax legislation on stock prices. For example, in 1997, many predicted the reduction of the capital gains tax rate would spur savings and investment, ultimately increasing stock val- 
ues, though perhaps preceded by an initial sell-off. Some doubted the cut could spur an already record-level stock market. Others foresaw disaster. For example, columnist John Rothchild (Fortune, April 28, 1997, p. 409) called the rate reduction, "the worst thing to happen to the stock market since Saddam Hussein invaded Kuwait." David Jones, analyst at Aubrey G. Lanston, summarized the confusion: "There's a huge amount of uncertainty about this-how much selling there will be, how much revenue generated, what the effect will be on stocks" (Boston Globe, June 22, 1997, p. E7). The same article quotes Brookings economist William G. Gale stating, "I can't venture a guess" about whether the cut will increase or decrease stock prices. A purpose of this paper is to sharpen forecasts of the stock price effects of future capital gains tax changes on stock prices by analyzing the conditions required for such changes to affect stock prices and reviewing initial research evaluating the 1997 and 1998 Acts.

Before this recent flurry of legislative action, the previous two changes in capital gains tax rates occurred in the Tax Reform Act of 1986 and the Economic Recovery Tax Act of 1981. Neither act provides a powerful setting for evaluating the stock market reaction to capital gains tax changes. Their development and complexity impede attempts to isolate those responses. Both involved months of debate and substantial restructuring of the tax system.

In contrast, the 1997 and 1998 changes to capital gains taxation potentially provide unusually powerful settings to isolate price effects. Neither bill was as comprehensive, as complex, or as controversial as the 1981 and 1986 Acts. With both bills, information about the capital gains tax changes appear to have been conveyed to the equity markets during a brief period, causing the stock market to adjust quickly its expectations about the probability of a change. If so, this facilitates isolation of the stock market reaction to capital gains tax changes, because prices should have impounded the changes during a narrow window.

An additional advantage of examining the recent Acts is that economic and technological changes (e.g., reduced brokerage fees and expanded use of stock options) since the 1980s have potentially altered the benefits of favorable long-term capital gains treatment for the stock markets. In particular, more individuals (the sole group benefiting from favorable long-term capital gains tax rates) now invest in equity, and their holdings are greater. As a result of the bull market, many shares are highly appreciated, subject to substantial capital gains taxes. Consequently, personal capital gains taxation may be more important in equity price formation now than in the past.

Recognizing the opportunity to recalibrate the relation between share prices and capital gains tax changes, four studies have assessed the stock 
market reaction to the 1997 and 1998 Acts. Each analysis employs event study methodology. Firm-level price reactions are examined using research designs that assess differences in share price responses across firms. The tests control for indirect macroeconomic factors that affect all sectors.

Three studies evaluate share price responses during the development of TRA 97 and following its enactment. Lang and Shackelford (2000) find that when Congress and the White House agreed to cut the capital gains tax rate in May 1997 (three months before the bill's passage), returns on high-dividend-yield stocks were lower than those on stocks with lower dividend yields. They interpret these findings as evidence that investors discriminated among companies based on the probability that shareholder returns would be affected by the new capital gains tax rates.

Sinai and Gyourko (1999) test whether investors discriminated between real estate investment trusts (REITs) organizational forms based on the potential tax savings to individuals selling real estate. Consistent with the capital gains rate reduction lowering the cost of purchasing real estate, they find that in 1997 traditional REITs outperformed acquisitive UPREITs (an organizational form that benefited less from the rate reduction).

Guenther (1999) also investigates TRA 97. He seeks to determine whether individual shareholders deferred selling appreciated stock until the effective date for the lower rate was finalized. Consistent with a sellers' strike, Guenther finds lower ex-dividend day returns immediately preceding the effective date.

Blouin, Raedy, and Shackelford (1999b) evaluate the stock price effects of the IRSRRA 98 reduction in the long-term capital gains holding period. They find that appreciated firms whose initial public shareholders met the 12-month holding period, but not the 18-month period, underperformed during the conference committee's deliberations that first proposed repeal of the 18-month period. They conclude that shortening the holding period triggered a sell-off that depressed share prices.

Overall, the evidence in these studies is consistent with the personal taxation of capital gains affecting individual firms' prices. The results imply that stock prices respond to capital gains tax changes as though equity values capitalized anticipated capital gains taxes. In addition, the response is large, quick, and often complete by public announcement of the change.

The next section reviews the taxation of capital gains and losses. Section 3 outlines seven necessary conditions for capital gains taxes to affect stock prices. Section 4 models the stock-price effect of a change in the capital gains tax rate. Section 5 presents results from the three studies of TRA 97. Section 6 discusses results from the study of the IRSRRA 98. Section 7 draws four inferences from the studies. Closing remarks follow. 


\section{INDIVIDUAL TAXATION OF CAPITAL GAINS AND LOSSES}

Individual investors are taxed differently on the sale of capital assets, depending on the length of time that they hold the property. Gains and losses from sales of property held longer than the specified holding period are long-term. All other realizations are short-term. Table 1 shows that over the last forty years, the holding period required for long-term classification has ranged from 6 to 18 months. In all years, except 19981990 (when no differential existed), long-term capital gains have been tax-favored compared with short-term capital gains. From 1970 through 1986, short-term capital losses were tax-favored compared with the longterm capital losses because investors could deduct only half of their longterm capital losses.

Computation of the taxable income arising from capital transactions involves two separate nettings-short-term capital gains netted against short-term capital losses, and long-term capital gains netted against long-term capital losses. If short-term capital gains exceed short-term capital losses and long-term capital gains exceed long-term capital losses, no further computations are required. The applicable tax rate for short-term capital gains applies to the net short-term capital gains (i.e., short-term capital gains less short-term capital losses), and the applicable tax rate for long-term capital gains applies to the net long-term capital gains (i.e., long-term capital gains less long-term capital losses).

Table 1, column (1), shows the change in marginal tax rates when a stock shifts from short-term to long-term, assuming the nettings yield both net short-term capital gains and net long-term capital gains. For example, under current law, if a one-dollar gain (loss) is recognized on property held one year or less, taxes increase (decrease) by 39.6 cents. If a one-dollar gain (loss) is recognized on property held more than one year, taxes increase (decrease) by 20 cents. Thus, when the stock shifts from short-term to long-term, the marginal tax rate applied to a realization changes by 19.6 percentage points [bottom row of Table 1 , column (1)]. ${ }^{1}$

Likewise, if the two nettings yield both net short-term capital losses and net long-term capital losses, the applicable deduction rate for short-term capital losses applies to the net short-term capital losses, and the applicable deduction rate for long-term capital losses applies to the net long-term

1 The gain or loss from the potential realization is assumed not to alter the overall gain or loss position. If the investment being evaluated would create sufficient gain or loss to alter the overall position, the marginal tax rate calculation becomes endogenous to the decision, and the analysis is beyond the scope of this paper. 


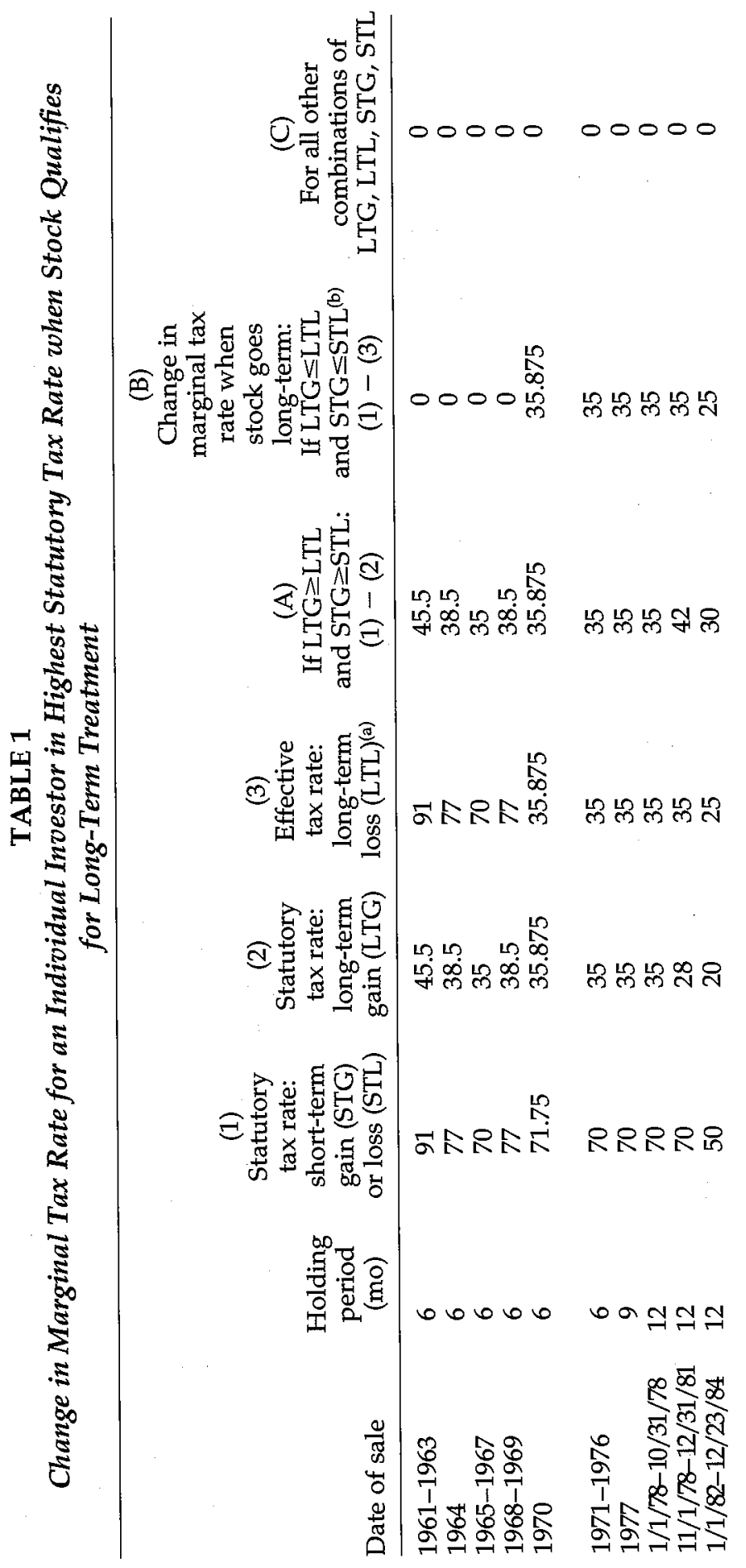




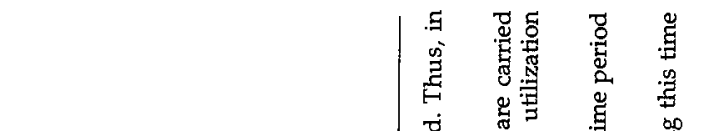

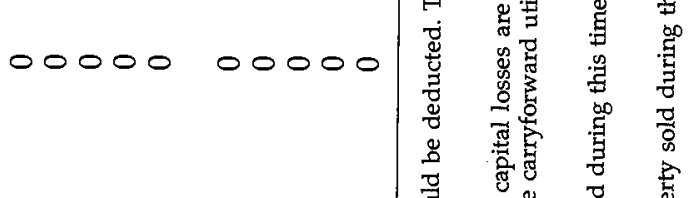

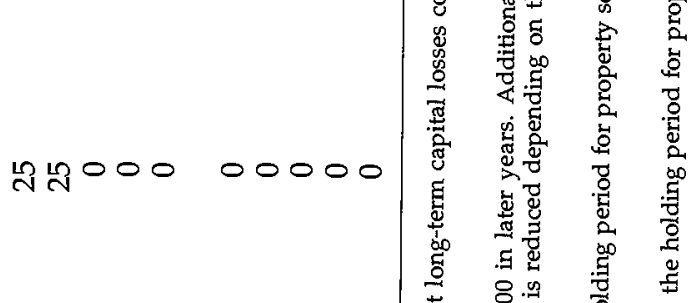

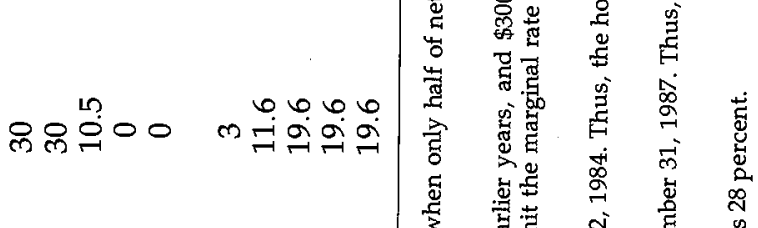

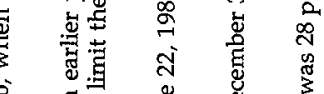

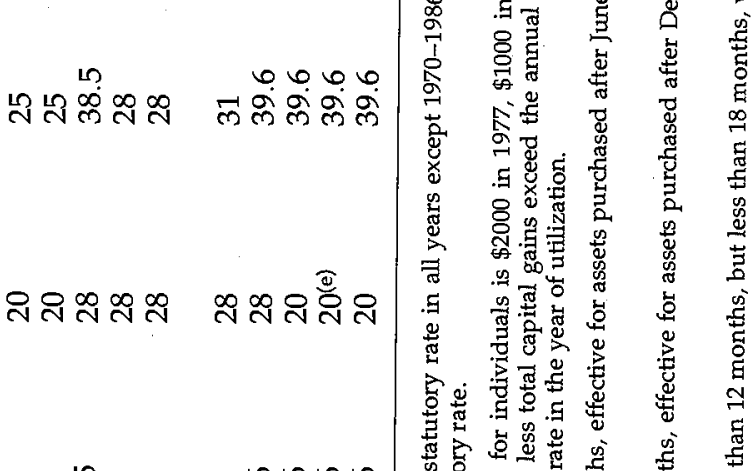

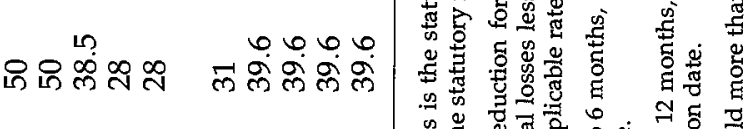

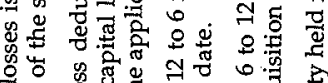

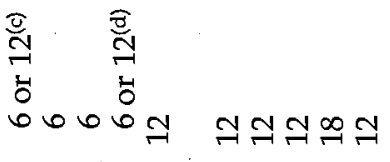

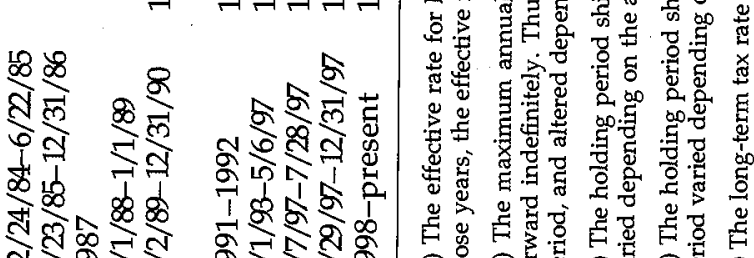

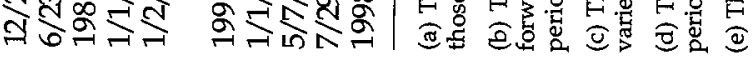


capital losses. Table 1, column (2), shows the change in marginal tax rates when a stock shifts from short-term to long-term, assuming the nettings yield both net short-term capital losses and net long-term capital losses. Because short-term and long-term losses provide the same deduction under current law, the marginal tax rate change is zero when a stock passes from short-term to long-term [bottom row of Table 1, column (2)]. Note that the marginal tax rate change is zero regardless of whether the specific stock being evaluated has appreciated or depreciated.

If one netting yields net capital gains and the other netting yields net capital losses, a single income or deduction amount is computed from the difference in the two initial nettings. For example, assume long-term capital gains are 9 , long-term capital losses are 4 , short-term capital losses are 3 , and short-term capital gains are 2 . The initial nettings will yield net long-term capital gains of 5(9-4) and net short-term capital losses of 1 (32). A final netting produces a single net long-term capital gain of $4(5-1)$. Here, the only gain or loss included in the individual's taxable income is the net long-term capital gain of 4 , which is taxed at the long-term capital gains tax rate.

If this additional netting is required, then taxes are unaffected by whether a gain is long-term or short-term or whether a loss is long-term or short-term. To illustrate, suppose the individual in the preceding example delays the sale of an appreciated property until it qualifies for a long-term gain. The long-term capital gains increase to 10 , and the shortterm capital gains fall to 1 . Net long-term capital gains are now $6(10-4)$, and net short-term capital losses are now $2(3-1)$. The final single net long-term capital gains is unchanged at $4(6-2)$. Likewise, if the individual accelerates a sale, increasing the short-term gain and decreasing the long-term gain, then the total taxes are unaffected. Shifting losses between long-term and short-term status also does not affect the individual's tax liability.

To restate using current rates, assume (1) short-term capital losses exceed short-term capital gains, (2) long-term capital gains exceed long-term capital losses, and (3) total (short- plus long-term) capital gains exceed total capital losses. Under these facts, an additional dollar of long-term capital gains increases taxes by 20 cents, because net long-term capital gains have risen by 1 dollar. However, an additional dollar of short-term capital gains also increases taxes by 20 cents. The short-term gain reduces the amount by which the short-term losses exceed the short-term gains. Since short-term losses (net of short-term gains) offset long-term gains, the effect of an additional dollar of short-term capital gain is to increase net long-term capital gains by 1 dollar and taxes by 20 cents. 
Similarly, an additional dollar of long-term capital losses reduces taxes by 20 cents, because long-term capital gains, net of long-term capital losses, have fallen by 1 dollar. An additional dollar of short-term capital loss also decreases taxes by 20 cents. The short-term loss increases the amount by which the short-term losses exceed the short-term gains by 1 dollar. Since short-term losses (net of short-term gains) offset long-term gains, the effect of an additional dollar of short-term capital gain is to decrease net long-term capital gains by 1 dollar and reduce taxes by 20 cents.

To summarize, the marginal tax rate associated with the sale of a stock must be evaluated with a portfolio perspective where all other gains and losses are considered. Under current law, if the investor's portfolio of gains and losses creates either net long-term capital losses or net shortterm capital losses, then the marginal tax rate for a particular stock does not change when the stock passes the one-year holding period. The preferential long-term capital gains tax rate only affects individuals whose total long-term capital gains equal or exceed long-term capital losses and whose total short-term capital gains equal or exceed short-term capital losses [Table 1, column (1)]. These conditions hold regardless of whether the stock being evaluated has appreciated or depreciated. The only exception to this rule, which footnote 1 assumes is not applicable, occurs if the gain or loss from the stock being evaluated alters the overall portfolio gain or loss position. In this case, the marginal tax rate becomes endogenous to the decision to sell. Such analysis is beyond the scope of this paper.

The netting provisions introduce a timing dimension to the investor trading decision. Generally, investors maximize returns by realizing taxfavored long-term capital gains and deductible capital losses in different years (Constantinides, 1984). Separation prevents the loss of tax-favored treatment through the netting of long-term capital gains against capital losses. Consistent with separation, Dhaliwhal and Trezevant (1993) find that January returns are greater for appreciated (depreciated) stock after a year with a bull (bear) market. Their results are consistent with investors selling appreciated (depreciated) stock during the final days of December of bull (bear) market years, segregating long-term gains and deductible losses between years.

Finally, the total deduction for capital losses, both long-term and short-term, is currently limited to $\$ 3000$ annually for individuals. The limit was $\$ 2000$ in 1977 and $\$ 1000$ in earlier years. Excess capital losses are carried forward indefinitely, retaining their long-term and shortterm status. Thus, the marginal tax rate for a carried-forward deduction is reduced for the time value of money. 


\section{NECESSARY CONDITIONS FOR CAPITAL GAINS TAXES TO AFFECT STOCK PRICES}

At least seven conditions must hold for stock prices to be affected by a change in the long-term capital gains tax rate. These factors are equally applicable to a change in the holding period.

\subsection{Condition 1: Individual as Marginal Investor}

The marginal shareholder must be an individual or a flow-through entity (e.g., mutual fund, partnership, S corporation, limited liability corporation) that passes capital gains to individual tax returns. Other investors, such as corporations, qualified plans (e.g., pensions), tax-exempt organizations, and foreign investors, face the same tax rate regardless of the duration the property is held. If the marginal shareholder is not an individual in a tax bracket where long-term capital gains are taxed favorably, changes in the capital gains tax rates should not affect prices. Extant studies (e.g., Miller and Scholes, 1982) present evidence consistent with the marginal investor not being a taxable individual investor.

\subsection{Condition 2: Net Portfolio Gain Position}

The long-term capital gains tax rate must apply to the marginal investor's realization after applying the netting provisions discussed above. For example, in Table 1, column (A), when the investor's portfolio of shortterm capital gains exceeds or equals short-term capital losses and longterm capital gains exceed or equal long-term capital losses, the long-term capital gains tax rate applies to a realization. More generally, long-term capital gains must exceed long-term capital losses and the excess of shortterm capital losses over short-term capital gains, if any. Otherwise, the investor's marginal tax rate is unaffected by a change in the long-term capital gains tax rate.

An effect of the netting provisions is to relax the link between capital gains tax changes and the pricing of specific stocks. Instead of the applicable tax rate being determined by the stock's price and the investor's tax basis, it depends on the investor's portfolio of gains and losses throughout the year. Moreover, determination of the portfolio position is made annually, so the applicable tax rate is uncertain before year-end.

\subsection{Condition 3: Holding Period}

The marginal investor must be willing to invest for the requisite holding period. The advantage of long-term capital gains treatment must dominate nontax incentives to sell earlier, e.g., portfolio rebalancing. Al- 
though many shares are held for long periods, day traders and other individuals with short investment horizons may find the inducement of a lower tax rate insufficient to defer their sales.

To illustrate the coordination of taxes and market risk, let $P(1-\tau)+B \tau$ equal the after-tax proceeds, where $P$ is the sales price, $B$ is the tax basis, and $\tau$ is the long-term capital gains tax rate. A change in the long-term capital gains tax rate $(\Delta \tau)$ leaves the after-tax proceeds unchanged if the price falls by $\Delta \tau(P-B) /(1-\tau-\Delta \tau)$. For example, the benefit of TRA 97's 8-percentage-point decline in the long-term capital gains would have been fully offset by a price decline equal to 10 percent of the share's appreciation, i.e., $P-B$ (see footnote 4 in Guenther, 1999, for a similar analysis).

\subsection{Condition 4: Taxable Disposition}

The marginal investor must intend to dispose of the stock in a taxable transaction-specifically, secondary market trades, share repurchases, or corporate liquidation (Lang and Shackelford, 2000). Any other investment strategy (e.g., buy-and-hold or nontaxable disposition) renders capital gains taxes irrelevant. Although each trading day provides ample evidence that some individuals sell securities, many stocks likely are intended to be held until death, avoiding all income taxation on their appreciation. Some shares are intended to remain in family hands across generations through inter vivos gifts. Others are intended to be contributed to charities, avoiding all taxation on appreciation. Still others are intended to be exchanged for acquirer's stock in a tax-free reorganization. To the extent investors anticipate never selling their property in a taxable disposition, the influence of changes in the long-term capital gains tax rate on prices is diminished.

A nontaxable disposition method discussed at length in theoretical finance and public economics is the use of intricate deferral strategies (e.g., equity swaps) that enable investors to diversify without triggering a capital gain (see, e.g., Constantinides, 1983, 1984; Stiglitz, 1983; Scholes and Wolfson, 1992; Shackelford, 2000). Whether perfect substitutability among financial assets precludes the possibility of taxes affecting equity prices is an empirical question (see Poterba's 1987a analysis). However, anecdotes in the business press (e.g., Estée Lauder's wellpublicized shorting-against-the-box) suggest that some investors at least partially avoid capital gains taxes.

\subsection{Condition 5: Compliance}

The marginal investors must pay the capital gains tax generated at realization. Noncompliance with the capital gains tax law would weaken 
equity reactions to capital gains tax changes. Landsman, Shackelford, and Yetman (1999) identify three reasons that capital gains noncompliance may flourish. First, the transactions creating capital gains are usually large, increasing the returns to evasion. Second, capital gains transactions are irregular and infrequent, making it difficult for the taxing authorities to establish baselines cross-temporally or across taxpayers. Third, tax bases are not tracked by third-party reports, and unless brokers are employed, no third-party reports are required to track sales proceeds.

Unfortunately, too little is known about capital gains tax compliance rates to assess their effect on the relation between capital gains taxes and equity. The nearly sole source of information, Internal Revenue Service estimates from the nine Taxpayer Compliance Measurement Program (TCMP) surveys from 1965 to 1988, indicates that the percentage of actual capital gains that appear on tax returns ranges from 61 percent in 1976 to 93 percent in $1988 .^{2}$ This compares with 99-percent compliance for wages and 98-percent compliance for interest in the 1988 TCMP survey. Examining data from six TCMP surveys, Poterba (1987b) adds that capital gains tax compliance is decreasing in marginal tax rates.

\subsection{Condition 6: Alteration of Expectations}

The change in capital gains tax policy must alter the marginal investor's expectations about the capital gains tax rate that will apply when the stock is sold. Investors likely perceive that the life of any change in capital gains tax policy is short. The taxation of capital gains and losses has been controversial for decades, and policymakers continually advance proposals for change, including elimination. Unless selling is anticipated in the immediate future, an investor likely relies little on a change in current capital gains tax rates to forecast the relevant rate at disposition. Thus, the impact of a change in capital gains taxes is diminishing in the individual's investment horizon.

\subsection{Condition 7: Inelastic Supply}

Inelasticities in the supply of capital must prevent immediate readjustment throughout the economy following a change in the long-term capital gains tax rate. For example, suppose reductions in long-term capital gains tax rates attract individual investors. The surge of individuals will apply upward price pressure and decrease equity returns to nonindividual investors. Lacking transaction costs, nonindividual investors would imme-

2 In his review of 1979 tax returns, Thompson (1987) notes that the capital gains tax compliance rate for stocks is higher than for business property and personal residences. 
diately shift from equities to investments less favorably taxed from an individual's perspective. The downward price pressure from nonindividuals leaving the market could offset the upward price pressure from individuals entering the market, leaving stock prices unaffected.

\subsection{Summary}

To summarize, all seven of the above conditions must hold for a change in the long-term capital gains tax rate to affect prices. If any condition does not hold, a firm's stock price will be unaffected by a change in capital gains-tax policy, except through indirect macroeconomic shifts. No direct link between the change and the firm's price will occur. It seems reasonable that for at least some companies, all seven conditions will not hold. Thus, for at least those companies, a change in the capital gains tax rate will not affect equity prices.

\section{MODEL}

Lang and Shackelford (2000) assume the seven conditions hold and model the share-price effects of a change in the long-term capital gains tax rate. Their model, reproduced below, provides a useful benchmark for predicting the stock-price reaction to a change in the long-term rate. They assume that the present value of a firm's future free cash flows ( $F$ per period) and the present value of its shareholder distributions $\left(D_{1}\right.$ is the initial distribution) can be equated with a distribution growth rate $\gamma$ :

$$
\sum_{n=1}^{\infty} \frac{F}{(1+r)^{n}}=\sum_{n=1}^{\infty} \frac{D_{1}(1+\gamma)^{n-1}}{(1+r)^{n}}
$$

The share price at time $t\left(P_{t}\right)$ equals the expected dividends at $t+1$, after shareholder dividend taxes $\left(\tau^{d}\right)$, plus the anticipated sales price at $t+1\left(P_{t+1}\right)$, less shareholder capital gains taxes $\left(\tau^{\mathcal{c}}\right)$ on the change in price, discounted at $r$ :

$$
P_{t}=\mathrm{E}_{t} \frac{P_{t+1}+D_{t+1}\left(1-\tau_{t+1}^{d}\right)-\left(P_{t+1}-P_{t}\right) \tau_{t+1}^{c}}{1+r} .
$$

If $\tau_{t}^{c}=\tau^{c}$ and $\tau_{t}^{d}=\tau^{d}$ for all $t$, current prices $P_{0}$ can be expressed as

$$
P_{0}=\frac{D_{1}\left(1-\tau^{d}\right)}{r\left[\tau^{c}+\left(D_{1} / F\right)\left(1-\tau^{c}\right)\right]},
$$




$$
\frac{\partial P_{0}}{\partial \tau^{c}}=-P_{0} \frac{F-D_{1}}{\left(F-D_{1}\right) \tau^{c}+D_{1}} .
$$

The derivative implies that if a firm retains part of its internally generated cash flow, then a decrease in the capital gains tax rate increases its stock prices and the rise in stock price increases with the cash retained.

To gauge the economic magnitude of the 1997 capital gains tax cut, assume a firm is generating $\$ 25$ of $F$, is paying $\$ 5$ of $D_{1}$, and has a 10percent discount rate. Evaluated at the maximum statutory tax rates before the reduction, an unanticipated capital gains tax rate cut from 28 percent to 20 percent increases share prices by approximately 15 percent. If the firm's dividend yield is one percentage point greater (less), then prices rise by about 12 (20) percent, a 3- (5-)percentage point change in returns. These estimates likely provide an upper bound for actual stock price reactions, because they assume all investors are affected by the rate change, the rate change is fully unanticipated and immediately enacted, dividend policies are immutable, and future distributions and taxes are certain.

Klein (1999) shows that this model depends critically on the assumption of no unrealized gains at the beginning of the investment period. If investors have unrealized gains, a reduction in the capital gains tax rate could actually reduce stock prices. This counterintuitive result occurs because sellers now demand less compensation from buyers to trade. Thus, the directional prediction associated with a change in the capital gains tax rate depends on whether the stock's appreciation has occurred in the past or is anticipated in the future.

Even if all seven conditions are met and the model correctly depicts the effects of capital gains taxes on share prices, it remains an empirical issue whether the price pressure applied by the capital gains tax policy changes is sufficient to move stock prices. To make that assessment, four empirical studies have recently analyzed TRA 97 and IRSRRA 98. Each attempts to determine whether stock price movements around the legislative changes are consistent with capital gains taxes affecting equity values. The next two sections provide a summary of each study's motivation, design, and findings.

\section{TAXPAYER RELIEF ACT OF 1997}

\subsection{Summary of Lang and Shackelford (2000) (LS)}

This study analyzes stock price reactions to the 1997 announcement that capital gains tax rates would be reduced. Tax legislative information 
usually leaks to the market over a long period as legislation slowly works through Congress. With TRA 97, investors may have changed their expectations about a capital gains tax rate change in a more compressed period. On April 30, 1997, after months of uncertainty about capital gains tax legislation, the Congressional Budget Office released an unscheduled, favorable revenue estimate. The next morning, May 1, 1997, the Wall Street Journal and the New York Times reported that the CBO release had enabled negotiators to finalize the budget, including a capital gains tax reduction.

The following day, May 2, 1997, the Clinton administration and congressional leaders announced general agreement on the fiscal 1998 budget. Included in the accord was a commitment to an unspecified reduction in the maximum statutory long-term capital gains tax rate for individuals, which was eventually codified in TRA 97 . The business press immediately speculated that the capital gains tax reduction would shuffle individual shareholdings and depress the market. For example, the Wall Street Journal (May 5, 1997) quoted an unnamed market strategist as predicting the capital gains tax cut "would attract investor attention even more toward stocks with a high probability of capital appreciation and away from dividends" (p. C12). However, they warned that ". . . , a burst of selling may hit the markets, strategists say. That could be the reaction, at least temporarily, as investors with big long-term profits rush to lock in their gains" (p. C1).

If the $\mathrm{CBO}$ release and the subsequent accord substantially changed the probability that capital gains tax rates would be cut, then the market response to the capital gains tax rate reduction should have been concentrated over a few days. LS hypothesize that stock returns during that week were negatively correlated with dividend yields because the promise of a lower capital gains tax rate was less relevant for firms paying (large) dividends. ${ }^{3}$ Applying a market-model approach, they investigate the stock-price reaction of dividend-paying and non-dividend-paying stocks during the budget-accord week. The analysis is conducted on the 2,000 largest U.S. corporations as reported by Datastream for the 129 weeks from January 1995 through the event week $(239,296$ observa-

${ }^{3}$ LS note the similarity the spirit of their analysis and a Wall Street Journal (April 25, 1997) report that Brian Wesbury, chief economist at the Chicago bond firm of Griffin, Kubik, Stephens \& Thompson, characterized the Nasdaq Composite as an indicator of the market's expectations of the future capital gains tax rate, "a little cap-gains futures contract." Wesbury related movements in the Nasdaq since November 1996 to changes in the probability of a capital gains tax rate reduction. The DJIA was termed less sensitive to capital gains tax changes because its stocks "throw off a relatively heavy share of their profits in dividends." 
tions). Of the 1,975 sample firms with complete data, 1,247 (63 percent) pay dividends.

LS find that the mean return during the accord week was 6.1 percent for dividend-paying stocks and 12.9 percent for the non-dividendpaying firms. Regression analysis is undertaken to control for possible nontax differences in return, such as risk. The regression summary statistics in Table 2, panel A confirm that non-dividend-paying companies outperformed dividend-paying companies during the event week. The regression coefficient on the variable of interest is -4.3 , indicating that, after controlling for risk, the returns of non-dividend-paying stocks exceeded the returns of other firms by 4.3 percentage points, on average.

Table 2, panel B shows results for a similar regression that substitutes

\section{TABLE 2 \\ Regression Coefficient Estimates \\ (t Statistics) (a) $^{(a)}$}

Panel A

Regression equation ${ }^{(b)}$ :

returns $_{i t}=\beta_{1}$ dividend $_{i}+\beta_{2}$ week $_{t}+\beta_{3}$ dividend $_{i} \times$ week $_{t}+\Sigma \beta_{4 i} S \mathcal{E} P 500_{i t}+\epsilon_{i t}$ $\beta_{3}=-4.3$

$t$ statistic $=-14.5$

Sample: 2,000 largest U.S. corporations as reported by Datastream for which complete data are available

Number of firms

1975

Number of observations

239,296

Panel B

Regression equation(b):

returns $_{i t}=\beta_{1}$ dividendyield $_{i}+\beta_{2}$ week $_{t}+\beta_{3}$ dividendyield $_{i} \times$ week $_{t}+\Sigma \beta_{4 i}$

$S \mathcal{E P} 500_{i t}+\epsilon_{i t}$

$$
\begin{aligned}
\beta_{3} & =-0.29 \\
t \text {-statistic } & =-5.1
\end{aligned}
$$

Sample: Dividend-paying stocks from the 2,000 largest U.S. corporations as reported by Datastream for which complete data are available

Number of firms

Number of observations

157,055

(a) Adapted from Lang and Shackelford (2000, Tables 2, 3). Dependent variable: weekly return.

(b) returns it $_{\text {it }}$ firm i's weekly return for the 129 weeks from January 1995 through the week of the budget accord; dividend $d_{i}=$ a categorical variable that equals one if firm $i$ paid a dividend within the prior year; week $k_{t}=$ a categorical variable that equals one if the budget accord occurred in week $t$; $S_{S E P 50 O_{i t}}=$ Standard \& Poor's 500 index if firm $i$ and week $t$, else zero; and dividendyield $d_{i}=$ firm $i^{\prime}$ s dividend yield. 
dividend yields for the dividend categorical variable and examines only dividend-paying stocks. The regression coefficient on the dividend yield is significantly negative, indicating that current dividend yields are correlated with stock-price performance during the budget reconciliation week. The coefficient estimate is -0.29 , indicating that a one-percentage-point decrease in the dividend yield results in a 0.29 percentage-point larger stock price increase on the announcement of the budget agreement.

In short, LS infer from their findings that equity price responses to the 1997 announcement of a reduction in the capital gains tax rate cut were decreasing in dividend yields. Contrary to some predictions, however, they find no evidence of a market slump driven by a reduction in the compensation for capital gains taxes that selling shareholders demand from buyers. Evaluation of returns throughout the summer of 1997 fails to find evidence of downward price pressure from selling shareholders.

\subsection{Summary of Sinai and Gyourko (1999) (SG)}

SG examine the same issue as LS, but with different firms and a different perspective. They test whether buyers compensate sellers for the capital gains taxes generated by sales. They examine the stock returns of purchasers of real estate to assess whether TRA 97 changed the compensation that buyers provide sellers.

SG conduct their study by examining equity real estate investment trusts (REITs), publicly-traded companies that own and operate real estate. Umbrella partnership REITs (UPREITs) are similar to other REITs, except that sellers of real estate to UPREITS can avoid immediate capital gains taxation if they are paid in UPREIT equity interests rather than cash. This nontaxable option is unavailable for traditional REITs. The distinction between traditional REITS and UPREITs is analogous to the distinction in the market for corporate control between taxable cash acquisitions and tax-deferred stock acquisitions.

SG hypothesize that TRA 97's capital gains tax rate reduction benefited traditional REITs more than UPREITs. All individuals selling to REITS potentially benefit from the rate reduction, while only individuals selling to UPREITs who receive cash (i.e., do not opt to receive taxdeferred equity interests) could benefit from the change.

To test the impact of TRA 97, SG evaluate the 1996 and 1997 daily stock prices for 129 traditional REITs and UPREITs. They predict that UPREITs that derive their value more from future acquisitions underperformed compared with similar traditional REITs in 1997. Their research design enables them to distinguish between performance in the two organizational forms, between years, and between more and less acquisitive 
TABLE 3

Regression-Coefficient Estimates and Standard Errors ${ }^{(a)}$

\begin{tabular}{lcc}
\hline $\begin{array}{l}\text { Explanatory } \\
\text { variable }^{(\mathrm{b})}\end{array}$ & $\begin{array}{c}\text { Coefficient } \\
\text { estimate }\end{array}$ & $\begin{array}{c}\text { Standard } \\
\text { error }\end{array}$ \\
\hline Y1997 & -0.017 & 0.042 \\
UPREIT & 0.067 & 0.037 \\
acquisition & -0.023 & 0.039 \\
Y1997 $\times$ UPREIT & -0.016 & 0.053 \\
Y1997 $\times$ acquisition & 0.047 & 0.055 \\
UPREIT $\times$ acquisition & 0.009 & 0.052 \\
Y1997 $\times$ UPREIT $\times$ acquisition & -0.146 & 0.073
\end{tabular}

Number of observations $=258$

Adjusted $R^{2}=0.07$

(a) Adapted from Sinai and Gyourko (1999, Table 8). Dependent variable: natural logarithm of the average share price in September less the natural logarithm of the average share price in January. Sample: 129 companies for 1996 and 1997.

(b) UPREIT $_{i}$ is 1 if firm $i$ is an UPREIT; Y1997, is 1 if period $t$ is 1997; acquisition $n_{i}$ is 1 if firm $i$ 's rent-tovalue ratio is below the weighted median for the sample.

firms. Table 3 reports the results from estimating the regression. As predicted, the regression results are consistent with TRA 97's capital gains tax rate reduction being more beneficial to traditional REITs than to UPREITs, conditional on the company's appetite for acquisitions.

A major distinction between SG's and LS's analyses of TRA 97 is the event period. Unlike LS, who find evidence that prices for the largest U.S. companies responded to the capital gains tax cut within one week, SG are unable to detect a response using a short window. Only when they investigate long event periods, e.g., January 1997 to September 1997, do they find evidence that the cut affected REIT prices. As the event period widens, the probability increases that it includes more of the period during which information moved prices. However, the probability also increases that the analysis is contaminated by other factors that differentially affect traditional REITs and UPREITs.

An explanation for this difference in the studies is that LS's setting provides more power. In their primary test, LS examine 239,296 firmweek price changes, while SG are limited to 258 firm-year price changes. In addition, LS examine the largest, more widely traded, presumably more efficiently priced U.S. equities, while SG evaluate an unusual organizational form in a single sector of the economy. Nonetheless, regardless of the event period, both studies find evidence that TRA 97's capital gains tax rate reduction impacted share prices in a predictable direction. 


\subsection{Summary of Guenther (1999)}

The May 2, 1997 announcement that the President and the Congress had agreed to reduce the capital gains tax rate did not state an effective date for the rate change. The business press reported that individual investors withdrew from the market to await an effective date. For example, the Wall Street Journal (May 5, 1997) reported ". . . a very noticeable seller's strike." It quoted David Shulman, chief equity strategist at Salomon Brothers in New York, stating, " I would suspect that as long as the effective date is in limbo, we would see delays in selling.' The worst thing Washington can do is 'to let this thing drag on' without details. 'Then you create economic uncertainty, and you can get a bubble on the way up. You could stop a whole series of business transactions right now in their tracks.' "The New York Times added that the reduction should "... in the short term, keep investors from selling until they know what the effective date of the tax cut will be." In response to purported market paralysis, Senate Finance Chairman William Roth and House Ways and Mean Chairman William Archer jointly announced May 7, 1997 that the effective date for any capital gains tax cut would be that day.

Guenther (1999) investigates whether shareholders delayed selling appreciated stock in anticipation of the 1997 reduction in the capital gains tax rate. He hypothesizes that if individuals withdrew from the market following the CBO announcement on April 30, 1997, and reentered following the May 7 announcement, then ex-dividend day returns for the week preceding the May 7, 1997 announcement should have been less than usual.

Extant studies (e.g., Elton and Gruber, 1970) document that exdividend days are marked by positive stock returns. This is consistent with individuals selling appreciated shares before the ex-dividend date at the favorable long-term capital gains tax rate, avoiding tax-disfavored dividends, and sharing their tax savings (the difference between the long-term capital gains rate and the ordinary tax rate) with other investors through upward price adjustments. However, if individuals await the new reduced rate and withdraw from the market, then no tax savings are available to share with remaining investors, eliminating the typical upward price pressure characterized by ex-dividend day returns.

To test this proposition, Guenther compares ex-dividend-day excess returns for the week ending May 7, 1997 (the day of the announcement of the effective date) with ex-dividend-day returns for the rest of 1997. Analyzing dividend-paying companies only, a pooled, cross-sectional, time-series model regresses excess returns on a categorical variable for 
TABLE 4

Regression Summary Statistics(a)

\begin{tabular}{lrcrc}
$\begin{array}{l}\text { Explanatory } \\
\text { variable }\end{array}$ & $\begin{array}{c}\text { Coefficient } \\
\text { estimate }\end{array}$ & $\begin{array}{c}\text { Standard } \\
\text { error }\end{array}$ & $t$ statistic & $\begin{array}{c}\text { Two-tailed } \\
p \text { value }\end{array}$ \\
\hline intercept & 0.0007 & 0.0007 & 0.95 & 0.342 \\
week & -0.0041 & 0.0019 & -2.11 & 0.035 \\
time1 & 0.0007 & 0.0008 & 0.95 & 0.340 \\
time2 & 0.0004 & 0.0006 & 0.60 & 0.552 \\
loss & -0.0015 & 0.0006 & -2.38 & 0.018 \\
discrete & 0.3452 & 0.1647 & 2.10 & 0.036 \\
yield & 0.1083 & 0.0793 & 1.37 & 0.172
\end{tabular}

Number of observations $=3785$

$F$ statistic $=2.923(p<0.0076)$

Adjusted $R^{2}=0.003$

(a) Adapted from Guenther (1999, Table 5). The dependent variable is firm $j$ 's daily return on exdividend day $t$ less the average of the daily returns on day $t$ for all sample firms except firms going exdividend within three days before or one day after day $t$; week $k_{t}$ is 1 if observation is an ex-dividend day $t$ from May 1, 1997 through May 7, 1997; time $1_{t}$ is 1 if observation is an ex-dividend day $t$ from May 8 , 1997 through July 27, 1997; time $2_{t}$ is 1 if observation is an ex-dividend day $t$ from July 28, 1997 through December 31, 1997; loss $j$ is 1 if the cumulative return for firm $j$ from April 1, 1996 through April 1, 1997 is negative; discrete $i$ is the difference between the dividend amount and the closest discrete tick price that is Iess than or equal to the dividend, divided by the ex-dividend-day-t stock price; yield $d_{j t}$ is firm $j^{\prime} s$ dividend amount divided by the ex-dividend-day- $t$ stock price.

the week and control variables. The analysis is conducted for 3,785 exdividend days spanning 983 firms.

Table 4 shows the regression coefficient estimate for the week's indicator variable is -0.41 percent ( $t$ statistic of -2.11 ), indicating excess exdividend-day returns for the week ending May 7, 1997 are significantly lower than those for other periods. This finding is consistent with a withdrawal of individual investors facing long-term capital gains rates during the week of uncertainty about the effective date.

\section{INTERNAL REVENUE SERVICE RESTRUCTURING AND REFORM ACT OF 1998}

\subsection{Summary of Blouin, Raedy, and Shackelford (1999b) (BRS)}

The Internal Revenue Service Restructuring and Reform Act of 1998 repealed TRA 97's extension of the holding period, reducing the long-term capital gains holding period from 18 months to 12 months, effective retroactive to the beginning of 1998 . The business press reported that the holding period reduction caused share prices to slump. For example, the Wall Street Journal (August 26, 1998, p. A1) linked the 1998 third-quarter 
stock market decline to selling pressure created by the reduction in the holding period. Marshall Front of Trees Front Associates observed "a much greater willingness" to sell among clients whose investments qualified for long-term capital gains under a 12-month holding period, but not under an 18-month period. Terry Banet, a vice president and portfolio manager at J.P. Morgan, cited the reduction in the holding period as "accelerat[ing] the sale of many of the positions" in stocks that qualified for long-term capital gains under the reduced holding period.

BRS test whether sell-offs, such as those implied by the Wall Street Journal, can be detected using conventional capital markets event study methodology. To maximize the power of their tests, BRS focus on the returns of initial public offerings. IPOs offer three advantages: (1) individual holdings are disproportionately large for IPOs, (2) the beginning of the holding period for shareholders who bought at the IPO is observable, and (3) the tax basis for those shareholders is measurable (Reese, 1998). To concentrate on IPOs for which the long-term capital gains tax policy is most relevant, BLS limit the analysis to IPOs that have appreciated since listing.

BRS's treatment group are IPOs whose initial public shareholders met the 12-month period, but not the 18-month period. The control group includes those same IPOs outside the event period and other IPOs whose listing occurred from 6 to 12 months earlier and from 18 to 24 months earlier. The sample includes 823 IPOs from 1996, 1997, and 1998.

Specifying precisely the period during which the market received information about the reduction in the holding period is difficult. Neither the House of Representatives' nor the Senate's original bill contained any capital gains provisions. On June 24, 1998, the conference committee, following closed sessions, produced the first bill eliminating the 18month holding period.

However, information potentially leaked to the market at least three times before the conference committee released its report. First, acting seemingly independently of the tax-bill deliberations, the House Budget Committee on June 5, 1998 issued its budget resolution for the fiscal year beginning October 1, 1998. The resolution assumed elimination of the 18-month holding period. Second, ten days later, on June 15, 1998, Senate Majority Leader Trent Lott expressed disappointment that the tax bill (then under consideration in the closed conference committee) did not eliminate the 18-month holding period for long-term capital gains. Third, the following day, House Speaker Newt Gingrich predicted that in September 1998 the tax committees would construct a bill eliminating the 18-month holding period. Because the event period cannot be specified precisely, BRS report the results for multiple event periods. 
To test the effects of the holding-period reduction, BRS regress daily stock returns on categorical variables that indicate whether the IPO's initial shareholders were affected by the change and that indicate the days included in the event period. The key variable is an interaction of the two indicator variables. The coefficient on the interaction indicates the mean daily percentage difference in returns between the treatment and control IPOs. BRS interpret a negative coefficient on the interaction as evidence that the treatment IPOs underperformed during the event period.

Table 5 presents results using various event periods. The coefficient on the interaction is most significantly different from zero $(0.05$ level

\section{TABLE 5}

Regression Summary Statistics ${ }^{(a)}$

\begin{tabular}{|c|c|c|c|c|c|}
\hline \multicolumn{6}{|c|}{ Regression model ${ }^{(\mathrm{b})}:$ returns $_{i t}=\beta_{0 \mathrm{t}}+\beta_{1}$ mid $I P \mathrm{O}_{i t}\left(1+\right.$ info $\left._{t}\right)+\epsilon_{i t}$} \\
\hline & \multirow[b]{2}{*}{ Test Period } & \multicolumn{2}{|c|}{ mid_IPO} & \multicolumn{2}{|c|}{$\operatorname{mid} I P O_{i t} \times \operatorname{info}_{t}$} \\
\hline & & Coefficient & $\begin{array}{c}t \\
\text { statistic }\end{array}$ & $\begin{array}{c}\text { Coefficient } \\
(-)\end{array}$ & $\begin{array}{c}t \\
\text { statistic }\end{array}$ \\
\hline Maximum $t$ statistic & $6 / 17-6 / 24$ & 0.018 & 0.49 & $-0.292^{* *}$ & -1.71 \\
\hline Full period & $6 / 5-7 / 22$ & 0.002 & 0.04 & 0.010 & 0.13 \\
\hline $\begin{array}{l}3 \text { days beginning with } \\
\text { budget report }\end{array}$ & $6 / 5-6 / 9$ & 0.014 & 0.37 & -0.202 & -1.19 \\
\hline Budget to conference & $6 / 5-6 / 24$ & 0.021 & 0.54 & $-0.149^{*}$ & -1.30 \\
\hline $\begin{array}{l}\text { Lott comment to } \\
\text { conference }\end{array}$ & $6 / 14-6 / 24$ & 0.017 & 0.45 & $-0.198^{*}$ & -1.33 \\
\hline $\begin{array}{l}\text { AP report and } \\
\text { conference bill }\end{array}$ & $6 / 23-6 / 24$ & 0.007 & 0.19 & -0.166 & -0.57 \\
\hline Conference report & $6 / 24$ & 0.008 & 0.21 & -0.433 & -1.05 \\
\hline Postconference & $6 / 25-7 / 8$ & -0.009 & -0.23 & 0.147 & 1.15 \\
\hline
\end{tabular}

**Significant at the 5-percent level, one-tailed test.

* Significant at the 10-percent level, one-tailed test.

(a) Adapted from Blouin, Raedy, and Shackelford (1999b, Table 4. Adjusted $R^{2}$ is 9 percent for all regressions.

(b) Sample: 61,968 daily returns from 1996, 1997, and 1998 initial public offerings. returns $s_{i t}=$ firm $i^{\prime}$ s daily stock return for day $t ;$ mid $\_P \mathrm{O}_{i t}=$ categorical variable that equals one if firm $i$ 's IPO occurred more than year, but no more than 18 months, before day $t$; info $f_{t}=$ categorical variable than equals one if day $t$ is during the event period. 
using a one-tailed test) for the period June 17, 1998 (the day following Speaker Gingrich's prediction) to June 24, 1998 (the day the conference committee released its bill and one day after press reports that the holding period would revert to 12 months). The estimate implies that over the six days, IPOs with initial public shareholders affected by the holding period underperformed by a mean daily return of 0.29 percent.

No other subperiods find significance at conventional levels. No evidence is produced consistent with the Wall Street Journal anecdote that prices were falling in the third quarter in response to the holding period change. The findings suggest that whatever price response occurred had been completed by the beginning of the third quarter.

\section{INFERENCES FROM TRA 97 AND IRSRRA 98 STUDIES}

As discussed above, the conditions under which TRA 97 and IRSRRA 98 modified capital gains tax policy provide unusually powerful settings for estimating relations between share prices and capital gains taxes. The four studies summarized above likely represent the first of many analyses of the 1997 and 1998 legislation that will advance our understanding of the effects of capital gains tax changes on stock prices. Together these studies provide at least four initial inferences that may be useful as Congress continues to revisit the appropriateness and level of capital gains taxation.

One, capital gains tax changes affect stock prices. Although each study analyzes a different sector of the stock market, all present evidence that share prices responded to the 1997 and 1998 legislation. The findings imply that the seven necessary conditions for capital gains taxes to affect share prices, outlined above, held during enactment of TRA 97 and IRSRRA 98. This suggests that, at least during these tax changes, individuals were the marginal shareholders for some firms.

Two, the stock market responds quickly to information about tax legislation. Notwithstanding SG's inability to detect a response using a short window (which is likely attributed to insufficient power), LS and BRS show that the price response is completed within days. These studies find no evidence of continuing tax effects, such as suggested by the Wall Street Journal's link between the 1998 legislation and stock market reactions weeks later.

Three, much of the market reaction has been completed when changes are publicly announced. For example, LS find prices moving before the May 2, 1997 budget accord, and BRS find share-price adjustments had completed their shift by the release of the conference committee's report. 
Price movement preceding public release of information is consistent with the adage that Wall Street "buys on the rumor and sells on the news." Investors trading initially on the "news" (e.g., budget accord announcement or the committee conference's release) would have missed much of the price reaction.

Four, the estimated stock-price responses to capital gains tax changes are of economic significance. Consider the annualized returns from the estimates in these studies. LS's estimates suggest that during the accord week, non-dividend-paying stocks outperformed other stocks by 350 percent using raw returns or 225 percent using risk-adjusted regression estimates. Guenther's estimates show that excess returns on ex-dividend days are normally 100 percent greater on an annual basis than those experienced around the rate change. BRS's estimates imply the holding-period change depressed the share prices of IPOs with affected initial public shareholders by 75 percent on an annual basis. SG's results do not permit the same annualized translation; however, their estimates imply that the capital gains rate reduction was borne fully by acquisitive UPREITs.

Compare these estimates with the American Council for Capital Formation (ACCF)'s widely reported testimony to the House Ways and Means Committee on June 23, 1999. Citing Wyss (1999), the ACCF stated that the 1997 rate reduction accounted for one-quarter of the market's subsequent 30-percent appreciation. During the week of the budget accord alone, LS find non-dividend-paying stocks outperformed dividendpaying firms by nearly 7 percent. Thus, LS report an incremental boost to non-dividend-paying stocks in one week that was almost as large as the two-year increase that the ACCF trumpeted as evidence that the stock market benefited from the 1997 rate reduction.

\section{CLOSING REMARKS}

In summary, the Taxpayer Relief Act of 1997 and the Internal Revenue Service Restructuring and Reform Act of 1998 provide a useful setting for reevaluating the effect of capital gains taxation on equity prices. Besides their being the first change in capital gains tax policy in over a decade, the market appears to have impounded information from both bills quickly, enabling recalibration of the effect of capital gains taxes on share prices.

In general, the evidence in the initial studies of the 1997 and 1998 legislation suggests that the incentives provided by favorable long-term capital gains taxation affect stock prices. Despite at least seven different conditions that must hold for capital gains tax policy to affect share values, the findings consistently show that stock prices capitalize capital gains 
taxes. The stock market response to capital gains tax changes appears rapid, complete by public announcement of the change, and material.

The results in these studies should interest tax and valuation scholars and be useful to policymakers as they revise capital gains tax policy. They contribute to a emerging literature-empirical (e.g., Guenther and Willenborg, 1999; Blouin, Raedy, and Shackelford, 1999a; Poterba and Weinsbrenner, 1998; Reese, 1998; Erickson, 1998; Landsman and Shackelford, 1995; Amoako-Adu et al., 1992; Hayn, 1989) and theoretical (e.g., Klein, 1999; Collins and Kemsley, 1999; Shackelford and Verrecchia, 1999; Balcer and Judd, 1987)_-linking stock market reactions to capital gains tax policy. The findings provide additional evidence that in at least some situations the marginal investor is an individual whose marginal tax rate changes when stocks cross from short-term to long-term classification. He invests shares for the requisite holding period, intends to sell in a taxable disposition, and complies with the capital gains tax law. His expectation of the applicable tax rate when he sells in the future is altered by the capital gains tax change, and supply inelasticities apparently prevent immediate economic readjustment. Together these papers raise doubts about prior assumptions that capital gains tax policy is of little relevance for equity price formation.

\section{REFERENCES}

Amoako-Adu, B., M. Rashid, and M. Stebbins (1992). "Capital Gains Tax and Equity Values: Empirical Test of Stock Price Reaction to the Introduction and Reduction of Capital Gains Tax Exemption." Journal of Banking and Finance $16: 275-287$.

Balcer, Y., and K. Judd (1987). "Effects of Capital Gains Taxation on Life-Cycle Investment and Portfolio Management." Journal of Finance 42:743-758.

Blouin, J., J. Raedy, and D. Shackelford (1999a). "Is the Marginal Shareholder an Individual? Capital Gains Taxes and Stock Reactions to Public Disclosures." Chapel Hill, NC: University of North Carolina. Working Paper.

, (1999b). "Stock Prices and Capital Gains Taxes: Evidence from the 1998 Reduction in the Long-Term Capital Gains Holding Period." Chapel Hill, NC: University of North Carolina. Working Paper.

Collins, J., and D. Kemsley (1999). "Capital Gains and Dividend Taxes in Firm Valuation and Corporate Financial Policy." Chapel Hill, NC: University of North Carolina. Working Paper.

Constantinides, G. (1983). "Capital Market Equilibrium with Personal Tax." Econometrica 51(May): 611-636.

(1984). "Optimal Stock Trading with Personal Taxes: Implications for Prices and the Abnormal January Returns." Journal of Financial Economics 13:65-89.

Dhaliwhal, D., and R. Trezevant (1993). "Capital Gains and Turn-of-the-Year Stock Price Pressures." Advances in Quantitative Analysis of Finance and Accounting 2:139-154. 
Elton, E., and M. Gruber (1970). "Marginal Stockholder Tax Rates and the Clientele Effect." Review of Economics and Statistics 52:68-74.

Erickson, M. (1998). "The Effect of Taxes on the Structure of Corporate Acquisitions." Journal of Accounting Research 36:279-298.

Guenther, D. (1999). "Investor Reaction to Anticipated 1997 Capital Gains Tax Rate Reduction. Boulder, CO: University of Colorado. Working Paper.

Gunther, D., and M. Willenborg (1999). "Capital Gains Tax Rates and the Cost of Capital for Small Business: Evidence from the IPO Market." Journal of Financial Economics 53(3):385-408.

Hayn, C. (1989). "Tax Attributes as Determinants of Shareholder Gains in Corporate Acquisitions." Journal of Financial Economics 23:121-153.

Klein, P. (1999). "The Capital Gain Lock-in Effect and Equilibrium Returns." Journal of Public Economics 71(3):355-378.

Landsman, W., and D. Shackelford (1995). "The Lock-in Effect of Capital Gains Taxes: Evidence from the RJR Nabisco Leveraged Buyout." National Tax Journal 48:245-259.

Landsman, W., D. Shackelford, and R. Yetman (1999). "The Determinants of Capital Gains Tax Compliance: Evidence from the RJR Nabisco Leveraged Buyout." Chapel Hill, NC: University of North Carolina. Working Paper.

Lang, M., and D. Shackelford (2000). "Capitalization of Capital Gains Taxes: Evidence from Stock Price Reactions to the 1997 Tax Reductions." Forthcoming Journal of Public Economics.

Miller, M., and M. Scholes (1982). "Dividends and Taxes: Some Empirical Evidence." Journal of Political Economy 90:1118-1141.

Poterba, J. (1987a). "How Burdensome Are Capital Gains Taxes?" Journal of Public Economics 33:157-172.

(1987b). "Tax Evasion and Capital Gains Taxation." American Economic Review 77(no. 2):234-239.

Poterba, J., and S. Weisbrenner (1998). "Capital Gains Tax Rules, Tax Loss Trading, and Turn-of-the-Year Returns." Cambridge, MA: National Bureau of Economic Research. Working Paper.

Reese, W. (1998). "Capital Gains Taxation and Stock Market Activity: Evidence from IPOs." Journal of Finance 53:1799-1820.

Scholes, M., and M. Wolfson (1992). Taxes and Business Strategy: A Planning Approach. Englewood Cliffs, NJ: Prentice-Hall.

Shackelford, D. (2000). "The Tax Environment Facing the Wealthy." Forthcoming in Does Atlas Shrug? The Economic Consequences of Taxing the Rich, J. Slemrod (ed.). Cambridge, MA: Harvard University and the Russell Sage Foundation. Shackelford, D., and R. Verrecchia (1999). "Intertemporal Tax Discontinuities." Chapel Hill, NC: University of North Carolina. Working Paper.

Sinai, T., and J. Gyourko (1999). "The Asset Price Incidence of Capital Gains Taxes: Evidence from the Real Estate Industry and the Taxpayer Relief Act of 1997." Philadelphia: University of Pennsylvania. Working Paper.

Stiglitz, J. (1983). "Some Aspects of the Taxation of Capital Gains." Journal of Public Economics 21(July):257-294.

Thompson, T. (1987). "1979 Individual Income Tax Capital Gains Income Reporting Noncompliance." In Trend Analyses and Related Statistics: 1987 Update. Washington: U.S. Department of the Treasury, Internal Revenue Service.

Wyss, D. (1999). "Capital Gains Taxes and the Economy: A Retrospective Look." Lexington, MA: Standard \& Poor's DRI. Working Paper. 